\title{
Resilience in tennis players with varying disabilities
}

\author{
María Agustina Viola and Yanina Vicente (ARG) \\ ITF Coaching and Sport Science Review 2015; 66 (23): 16 - 17
}

ABSTRACT

This paper intends to demonstrate that tennis players with different abilities have high levels of resilience, as well as a great number of other benefits, and, to encourage resilience while keeping this in mind.

\author{
Key words: adapted tennis, \\ different abilities, resilience, \\ sports psychology \\ Received: 22 April 2015 \\ Accepted: 15 Juy 2015 \\ Corresponding author: \\ María Agustina Viola \\ Email: \\ agusviola26@hotmail.com
}

\section{INTRODUCTION}

The subject of sport for people with different disabilities (wheelchair, amputees, Down syndrome, etc.) has gained increasing importance over the years. Today in Argentina, and all over the world there are associations, foundations, schools, clubs, etc, that include tennis practice for people with different handicaps. Among the most important we can mention, are the International Organisation for Competitive Sport for the Disabled from the IPC (International Paralympic Committee) and the IOSDs which are the five international sport organisations (CPIsRA, IBSA, INAS-FID, ISMWSF, ISOD). For adapted tennis, the ITF (International Tennis Federation) has the WTDF (Wheelchair Tennis Development Fund), which together with the Johan Cruyff Foundation, helps over 39 countries to develop this sport. In Argentina, the Argentine Adapted Tennis Association (AATA) was created in 1997.

\section{THEORETICAL FRAMEWORK}

According to the World Health Organisation, disability is a general term that includes deficiencies, constraints to the activity and restrictions to participation. Deficiencies are those problems that affect a body structure or function, constraints to the activity are difficulties to perform actions or tasks and restrictions to participation are problems to participate in vital situations. Therefore, disability is a complex phenomenon that reflects an interaction between the characteristics of the human organism and the characteristics of the society where humans live.

The condition of disability brings about many changes in a person's life, and so, it is necessary for him or her to use different mechanisms to adapt to this new situation and to learn to live with the restrictions these changes entail. There are persons who learn and benefit from the traumatic situations they have experienced. It is at this point where the concept of resilience enters into play (Suriá Martínez, 2012). There are different definitions, but the common factor to all of them is the capacity to face, overcome and benefit from the traumatic fact. It is worth mentioning that resilience is not a static characteristic of the personality, it can vary with the time and circumstances. It is for this reason that it is possible to work on those factors that encourage the resilient process. Sport can be an important tool to reach this target. From the psychological point of view, sport helps disabled persons to forget their barriers for a while, to strengthen their psyche (affection, emotions, control, perception, cognition) and creates room for self improvement in which the individual sets targets and gets better day after day overcoming and readjusting them (Zucchi, 2001).

\section{TARGETS, MATERIALS AND METHOD}

This paper intends to demonstrate that tennis players with different abilities have a high degree of resilience. In order to do so, we used the Resilience Scale (Wagnild \& Young, 1993) and interviewed tennis players with different abilities between 15 and 45 years old, men and women, and with a motor disability (either acquired or from birth) who practice the sport on a wheelchair or with a prosthesis.

\section{RESULTS}

The resilience scale indicates that the level of all players is above 121 points, that is to say, it is either moderate or high. Eight of them got a score of over 145 which shows a high degree of resilience. And it confirms the hypothesis that people with different abilities, who play tennis, have a high degree of resilience.

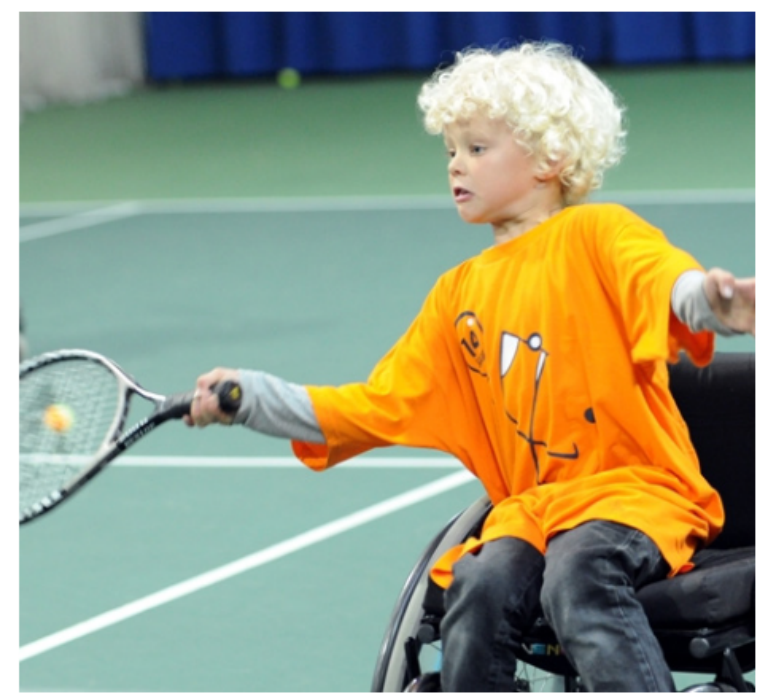

Then they were divided into subgroups (men-women, wheelchair-standing tennis, born- acquired disability, young- 
adults) and no significant differences were found among them, although adults over 35 got higher scores than the young, and the group of adaptive tennis players in a standing position did better than those who play on a wheelchair.

\section{CONCLUSIONS AND DISCUSSION}

Apart from the points that the scale provides, it is important to highlight the information retrieved the interviews: we found that not only does tennis favour resilience, it favours a number of other factors. It is surprising to see the number of players who say that tennis practice has helped them to be more independent, to demonstrate that they can, that they are able to do things by themselves. This can be seen in statements like: "because of my disability, I profited from it, but tennis has taught me I can be myself" (Lucas, 15 years old), "Tennis taught me to be independent, to open my arms and to face life" (Matías, 23 years).

Others emphasise this feeling of "not feeling less than others", to demonstrate that they can do just like others can, like "normal" people, Lucas says. "I felt that normal people, if I may put it that way, those who do not have a physical disability could practice sport, but...why not me?" and he stresses it again when he encourages others to play, "a person with disabilities or different abilities can do the same things or more than a normal person". So, I would tell a person with a disability to have the courage to do what he aims for, what he wants", and Matias says: "I feel tennis gives me the possibility of doing so, of running. I thought that I couldn't do it with the prosthesis, but I discovered that I can." Another aspect that players consider positive has to do with the physical and the social aspect, they say it helps them to not " to mope around all day", it helps them to meet new people and make friends, "sport helps me a lot, I am in contact with a lot of guys, sometimes you don't realise, but it helps you a lot, they teach you a lot, and you too, you are teaching them a lot of things, it is not just coming here and playing tennis and that's it, you go home there are many things that are brooding over in your head" (Florencia, 25 years). "Me, on my part, I can help other children with my experience, it is exactly what matters most, isn't it? [...] The truth is, it helped me, because I see that there are many people in a situation similar to mine and whether it is an amputation, or being plump, or being white or black, people discriminate against you, and when you feel discriminated against, you withdraw within yourself. I tell those people: "do get together, do create a group of people like you and then you learn" (Jessica, 35).

It is also important not to give up, not to take a passive attitude towards life, as Leonel put it, "I would tell them not to stay home sitting or lying in bed, to live their lives because life goes on. It is important, whatever happens, go on, and find something to do because life passes quickly and lying around is no use".

We believe that tennis can be a source of comfort to persons with different abilities. Our research was carried out only with players with motor disabilities, including wheelchair tennis and adapted standing tennis, but we must say that the research field is far broader. It would be interesting, and it is our purpose to extend this research, not only including other types of disabilities, but also the size of the sample and the benefits. Additional potential avenues for continued research could be to analyse the differences between those persons with different abilities who play sports and those who do not.
This research intends to spread the knowledge, support and favour sport practice in persons with different abilities.

\section{REFERENCES}

Dramisino, H., (2007). Resiliencia y deporte. Sinopsis, año 23 vol.43, 23-25.

Ospina Muñoz, D. E., (2007). La medición de la Resiliencia. Revista de Investigación y Educación en Enfermería, vol. XXV, núm. 1, 58-65.

Rodríguez, M., Pereyra, M. G., Gil, E., Jofré, M., De Bortoli, M, Labiano, L. M., (2009). Propiedades psicométricas de la escala de Resiliencia versión argentina. Evaluar, 9, 72-82.https://doi.org/10.35670/16674545.v9.n1.465

Ruiz, R., De la Vega, R., Poveda, J., Rosado, A., Serpa, S. (2012). Análisis psicométrico de la Escala de Resiliencia en el deporte del fútbol. Revista de psicología del deporte, vol. 21, núm. 1, 143- 151.

Suriá Martínez, R., (2012). Resiliencia en jóvenes con discapacidad. Boletín de psicología, vol. 105, 7589.www.aata.org.ar

www.itftennis.com, (2013), Wheelchair tennis development has a positive impact, says report.

Zucchi, D. G, (2001). Deporte y discapacidad. Revista Digital (www. efdeportes.com), año 7 vol. 43.

RECOMMENDED ITF TENNIS ACADEMY CONTENT (CLICK BELOW)

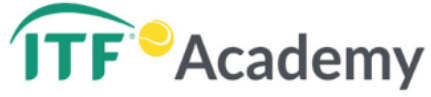

Copyright (c) María Agustina Viola and Yanina Vicente 2015

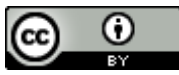

This text is under a Creative Commons BY 4.0

license

You are free to Share - copy and redistribute the material in any medium or format - and Adapt the content - remix, transform, and build upon the material for any purpose, even commercially under the following terms:

Attribution: You must give appropriate credit, provide a link to the license, and indicate if changes were made. You may do so in any reasonable manner, but not in any way that suggests the licensor endorses you or your use.

CC BY 4.0 license terms summary CC BY 4.0 license terms 